\title{
Lead (II) Remotion in Solution Using Lemon Peel (Citrus limonum) Modified with Citric Acid
}

\author{
Candelaria Tejada Tovar ${ }^{\# 1}$, AngelVillabonaOrtiz ${ }^{\# 2}$, Diofanor Acevedo Correa ${ }^{* 3}$, \\ NoridaPajaro Gómez ${ }^{\# 4}$, María Otero Amor ${ }^{\# 5}$ \\ ${ }^{*}$ Faculty of Engineering, Chemical Engineering program, Research Group IDAB, \\ University of Cartagena Av. El Consulado, St. 30 No. 48-152. Colombia. \\ * Faculty of Engineering, Research Group NUSCA, University of Cartagena Av. El Consulado, \\ St. 30 No. 48-152. Colombia. \\ ${ }^{1}$ ctejadat@unicartagena.com, ${ }^{2}$ avillabonao@unicartagena.edu.co, ${ }^{3}$ diofanor3000@gmail.com, 5 \\ maryamor24@hotmail.com,
}

\begin{abstract}
Lead remotion was evaluated in a synthetic solution with $100 \mu \mathrm{L}^{-1}$ of $\mathrm{Pb}$ (II), using the lemon peel as a biosorbent. The adsorption capacity of the lemon peel at different $\mathrm{pH}$ values and particle sizes was studied.A maximum adsorption capacity of $19.556 \mathrm{mg} \mathrm{g}^{-1}$ was achieved with $0.5 \mathrm{~g} \mathrm{of} \mathrm{biosorbent}$ dose at $\mathbf{p H} 6$, being able to remove up to $97.78 \%$ with the unmodified biomass and $93.83 \%$ after the cross-linking process of the adsorbent material.The adsorption kinetics is based on a Pseudo Second Order model for the biomass of lemon pre-treated with citric acid $\left(R^{2}=0.9586\right)$ and not pre-treated $\left(R^{2}=\right.$ 0.9408). It is concluded that lemon peel is a good precursor of lead adsorbent in aqueous solution.
\end{abstract}

Keyword - Biosorption, adsorption kinetics, Freundlich isotherm, lead.

\section{INTRODUCTION}

The increase in the concentration of heavy metals in water bodies caused by effluent discharges from anthropogenic activities is a growing environmental problem, because even at very low concentrations they are highly toxic[1], [2].Being cadmium, chromium, zinc, mercury, lead and nickel, the metals commonly found in wastewater; and of these, lead can affect the central nervous system, cause cancer and in more critical cases death due to its high toxicity even at low concentrations by binding with organic molecules[3], [4].

Once the metals enter the aqueous and terrestrial media, they participate in chemical interactions of complexing, oxide-reduction and precipitation, modifying the characteristics of toxicity and bioavailability by converting from one chemical form to another, varying their toxic effect according to the chemical species of the ion, the degree of acidity-basicity and organic and inorganic components of the environment; factors determining the chemical behaviour of the ion in the formation of soluble or insoluble chemical forms that condition risks to biota and public health[5]-[9].

Various technologies have been used for the removal of metal ions, among which are highlighted: chemical precipitation, chemical coagulation, oxidation, reduction, ion exchange, filtration, ultrafiltration, nanofiltration, adsorption (activated carbon, zeolites, silica gel), membrane technologies (reverse osmosis), electrochemical treatment (electrodialysis and electrocoagulation) and application of artificial wetlands (some stabilization), among others, resulting in many cases inefficient and costly [10]-[13]. Consequently, it is important to develop new detoxification technologies for such effluents and to chemically stabilize the compound[14]. This is why the development of new technologies based on domestic raw materials is a pending task for researchers from developing countries such as Colombia. Several studies have shown that the biomass of different species of lignocellulosic waste, bacteria, fungi and algae, are able to retain in their structures, metal ions that are found in aquatic environments [15]-[17].

Biosorption is a physicochemical process that includes the phenomena of adsorption and absorption of molecules and allows the retention of metal ions dissolved by materials with bioadsorbent capacity [18], [19].Containing the biosorbents of plant origin macromolecules (proteins, carbohydrates, carboxyl groups, hydroxyl, sulphates, phosphates and amino) that can trap metal ions by attracting opposing charges, thus favouring adsorption, depending on this process of $\mathrm{pH}$, temperature, ionic force of the medium, chemical characteristics of the metal, as well as the adsorbent capacity [20]-[23].

The search for low-cost materials with adsorbent capacity, such as agricultural waste and biological materials that allow ion stability and are resistant to disintegration and dissolution in the medium, have been tested to evaluate the efficiency of removal of soluble metal ions [24], [25].In addition, in order to improve the adsorption capacity of various materials, some authors have induced physical or chemical changes in different structures in order to increase the specific surface area of contact in two ways: between the bioadsorbent 
material and the ion and the number of loads and activity of the binding groups [26], [27].Among the vegetable residues recently used for adsorption of $\mathrm{Pb}$ (II) are African palm pre-treated with citric acid, olive pits modified with $\mathrm{HNO}_{3}, \mathrm{H}_{2} \mathrm{SO}_{4}$ and $\mathrm{NaOH}$, red seaweed, orange peel and tuna, dried or crushed orange peel, with and without cross-linking treatment (with $\mathrm{CaCl}_{2}$ ). In this context, the main objective of this work was to demonstrate the use of pre-treated lemon waste materials with citric acid as a source of biomass to remove $\mathrm{Pb}$ (II) from industrial wastewater[28]-[31].

\section{A. Preparation of the bioadsorbent}

The biomass was collected in the best possible condition to prevent its rapid decomposition, washed with abundant distilled water to eliminate tannins, reducing sugar resins and other impurities, which may intervene in the adsorption process.Then, it was dried in an oven at $90{ }^{\circ} \mathrm{C}$ for $24 \mathrm{~h}$. The size was then reduced by a roller mill for $20 \mathrm{~min}$. Sorting was carried out in a sieve shaker by selecting the sizes: $0.355 \mathrm{~mm}, 0.5 \mathrm{~mm}$ and $1 \mathrm{~mm}$ [28].

\section{B. Adsorbent characterization}

Once the bioadsorbent material had been prepared, the functional groups in the lemon peel were identified and the FTIR (Fourier Transformed Infrared Spectra) analysis was carried out[20].

\section{Modification of lemon peel with Citric Acid}

Once the lemon peel was conditioned, the modification was carried out with citric acid, for this purpose $40 \mathrm{~g}$ of biomass was mixed with $200 \mathrm{~mL}$ of a $0.6 \mathrm{M}$ citric acid solution. The mixture was left in agitation for $2 \mathrm{~h}$ at a temperature of $60^{\circ} \mathrm{C}$, after this time, the biomass was washed with abundant deionized water, then dried in an oven for $24 \mathrm{~h}$ at $55^{\circ} \mathrm{C}[32]$.

\section{Preparation of synthetic wastewater}

A Shaking incubator IN-666 was used to perform the adsorption tests, which previously contained an Erlenmeyer with $0.5 \mathrm{~g}$ of biomass and a Pb (II) solution at $100 \mu \mathrm{g} \mathrm{L}^{-1}$, which was prepared by adding $0.1 \mathrm{~g}$ of Pb $\left(\mathrm{NO}_{3}\right)_{2}$ to one $\mathrm{L}$ of deionized water[31].

\section{E. Bioadsorption tests}

The adsorption tests were carried out at a temperature of $25^{\circ} \mathrm{C}$ and $150 \mathrm{rpm}$ for $2 \mathrm{~h}$, the $\mathrm{pH}$ values were 2,4 and 6 , which were controlled by the addition of $0.1 \mathrm{~N} \mathrm{HCl}$ and $0.5 \% \mathrm{NaOH} \mathrm{p} \mathrm{v}{ }^{-1}$ [33].Final concentration analysis was performed by atomic absorption spectroscopy at $283.3 \mathrm{~nm}$ through mass balance[34]. After these tests the adsorption capacity was calculated using:

$$
q_{e}\left(m g g^{-1}\right)=\frac{V\left(C_{0}-C_{f}\right)}{m}
$$

Where, $q_{e}$ is the adsorption capacity in equilibrium $\left(\mathrm{mg} \mathrm{g}^{-1}\right), C_{o}$ and $C_{f}$ are the initial concentrations and equilibrium ( $\mathrm{mg} \mathrm{L}^{-1}$ ) of $\mathrm{Pb}$ (II) in the solution, $\mathrm{V}$ is the volume (L) of solution taken and $\mathrm{M}$ is the mass $(\mathrm{g})$ of adsorbent used[34].

\section{F. Adsorption kinetics}

In order to determine the $\mathrm{Pb}$ (II) remotion kinetics, batch-type experiments were carried out at 150rpm, by contacting different initial metal concentrations $\left(25,50,75,100 \mathrm{mg} \mathrm{L}^{-1}\right)$ for the unmodified lemon peel pretreated with citric acid.The experiments were performed at $\mathrm{pH} 3$, which was adjusted by adding drops of $\mathrm{NaOH}$ or $\mathrm{HCl} 0.1 \mathrm{~N}$ and $0.5 \% \mathrm{w} \mathrm{v}^{-1}$, respectively; and a ratio of $2 \mathrm{~g} \mathrm{~L}^{-1}$. The experiments were placed in $1000 \mathrm{~mL}$ beakers and shaken with a magnetic stirrer for $4 \mathrm{~h}[28]$, [31].

\section{RESULTS AND DISCUSSIONS}

The chemical-proximal analysis of the natural lemon peel showed a high carbon content of $38.48 \%$, followed by cellulose $18.49 \%$, lignin $7.22 \%$ and hemicellulose $6.07 \%$. In addition, it presented low ash content (3.68\%). Fig. 1 shows an FTIR analysis of the lemon peel to determine the functional groups that favour the lead adsorption process, as well as the lemon peel pre-treated with citric acid. 


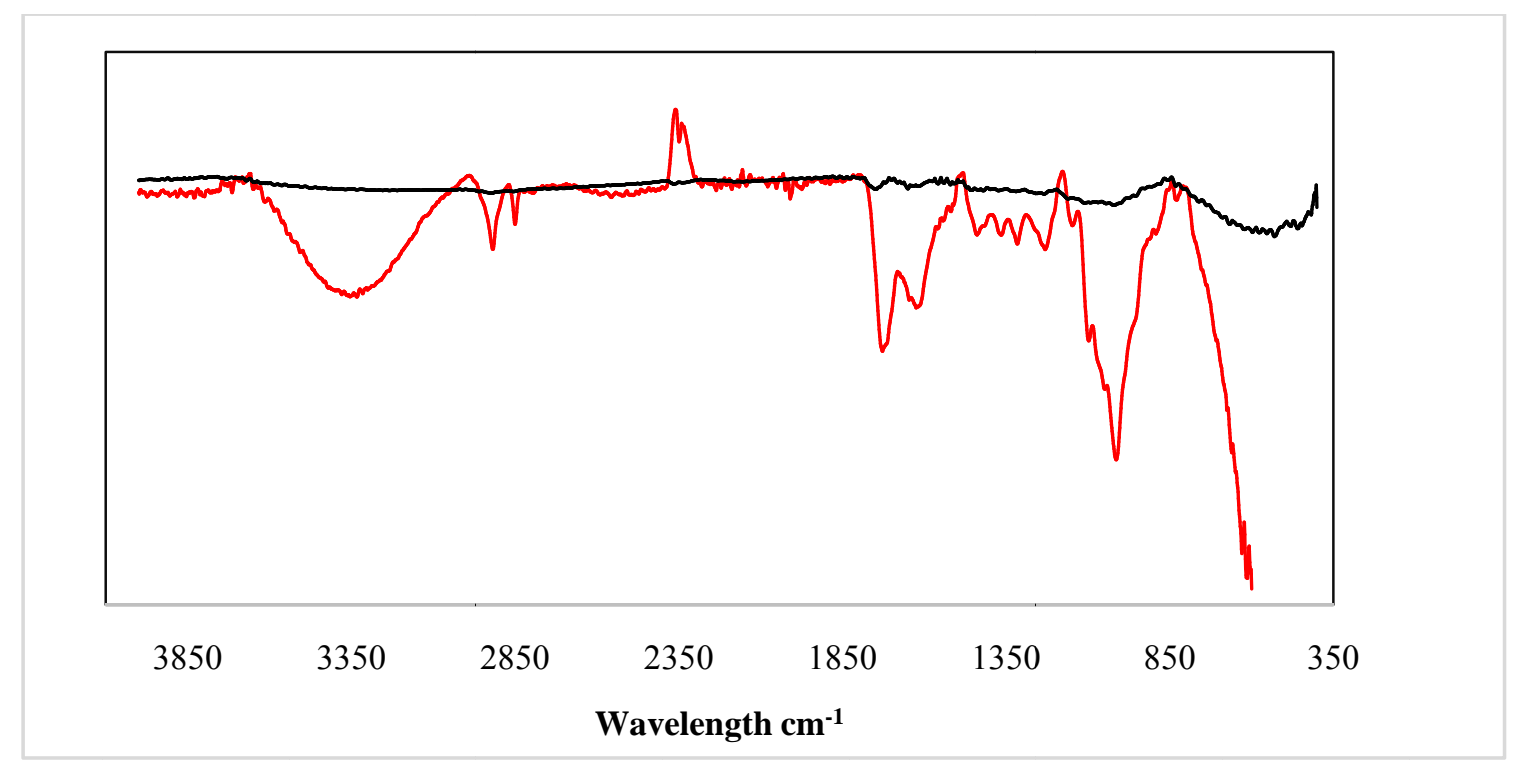

Fig. 1. FTIR analysis of modified ( - )and unmodified $(-)$ lemon peel before adsorption

Figure 2 shows the FTIR analysis of residual lemon biomass after adsorption without pre-treatment and modified with citric acid.

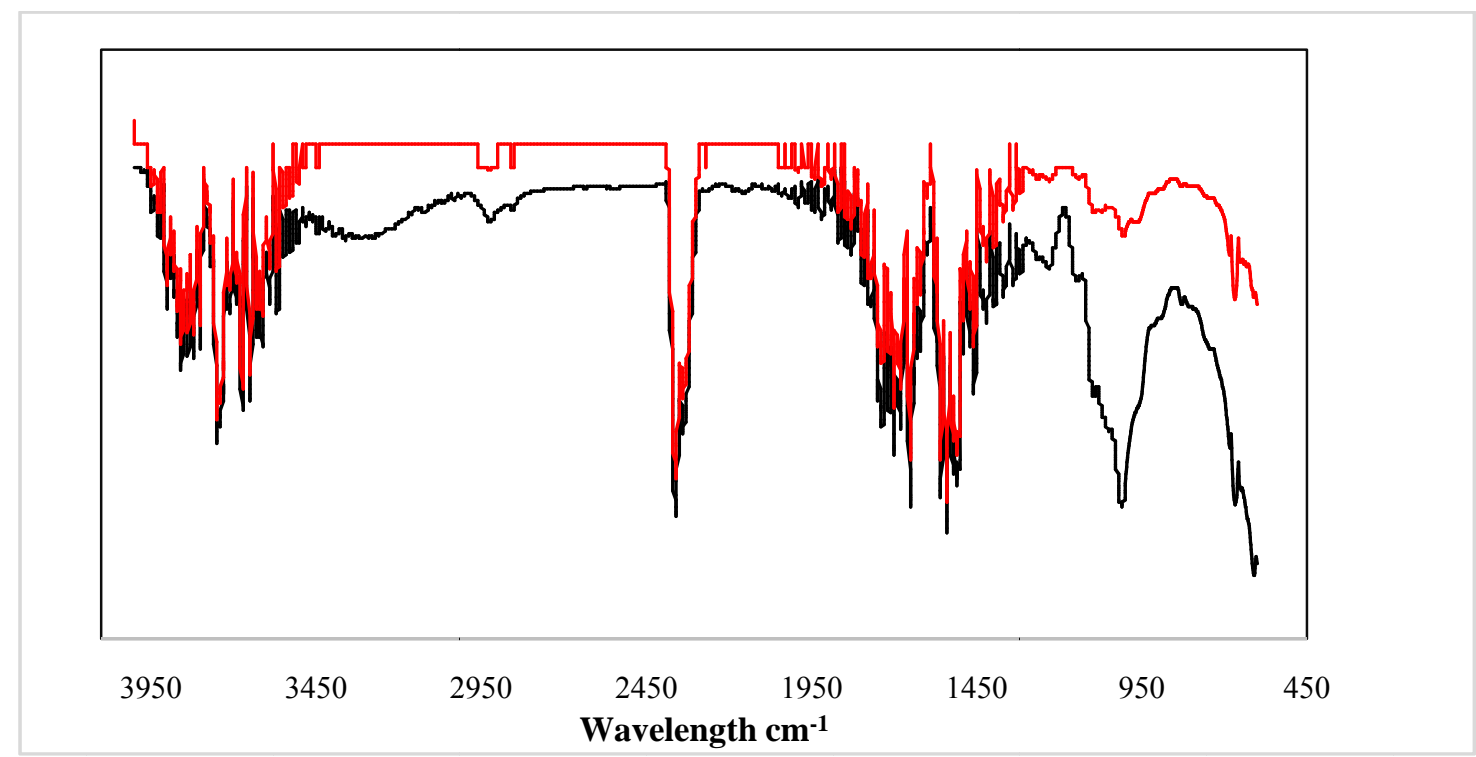

Figure 2. FTIR analysis of lemon biomass modified with citric acid ( - ) and unmodified ( $\longrightarrow$ ) after adsorption of $\mathrm{Pb}(\mathrm{II})$.

A. Effect of $\mathrm{pH}$ and particle size on adsorption

In this study, it was evaluated the effect of $\mathrm{pH}$ for values of 2,4 and 6, shown in Fig. 3 as well as the effect of particle size on adsorption with residual lemon biomass. 

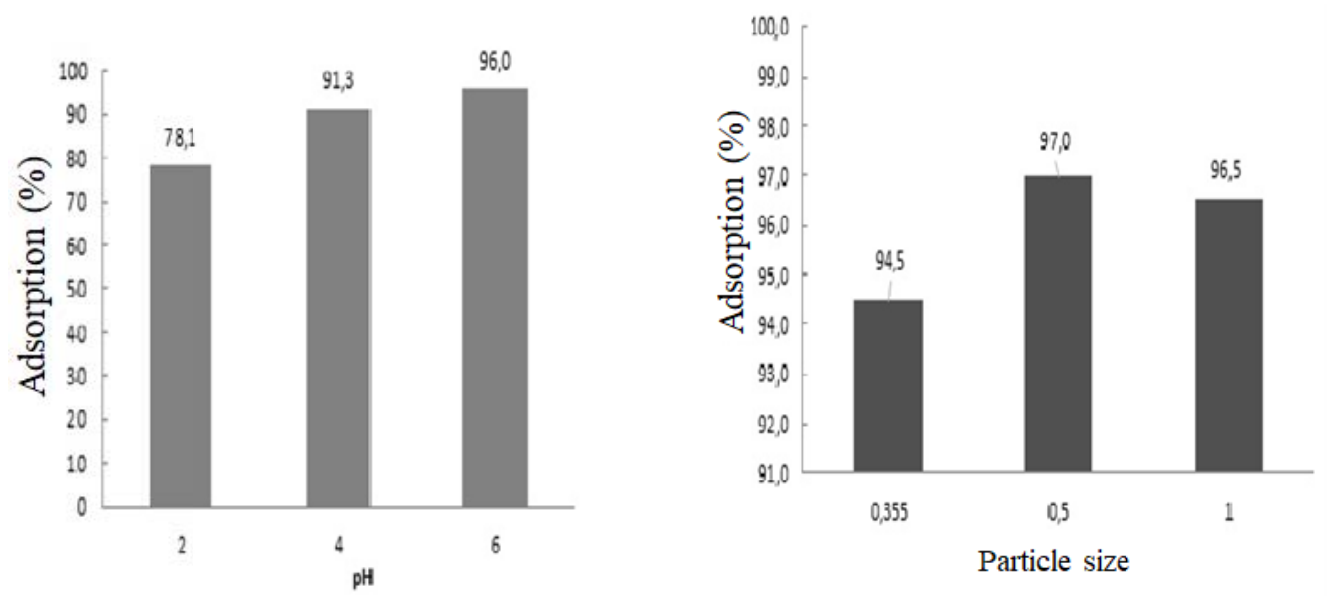

Fig. 3. Effect of $\mathrm{pH}$ (left) and particle size (right) on the adsorption of $\mathrm{Pb}$ (II)

\section{B. Adsorption kinetics}

To study adsorption kinetics, the Pseudo-first order, Pseudo-second order and Elovich models were taken into account. These mathematical models of non-linear fit were developed in the Microsoft Excel Solver tool.
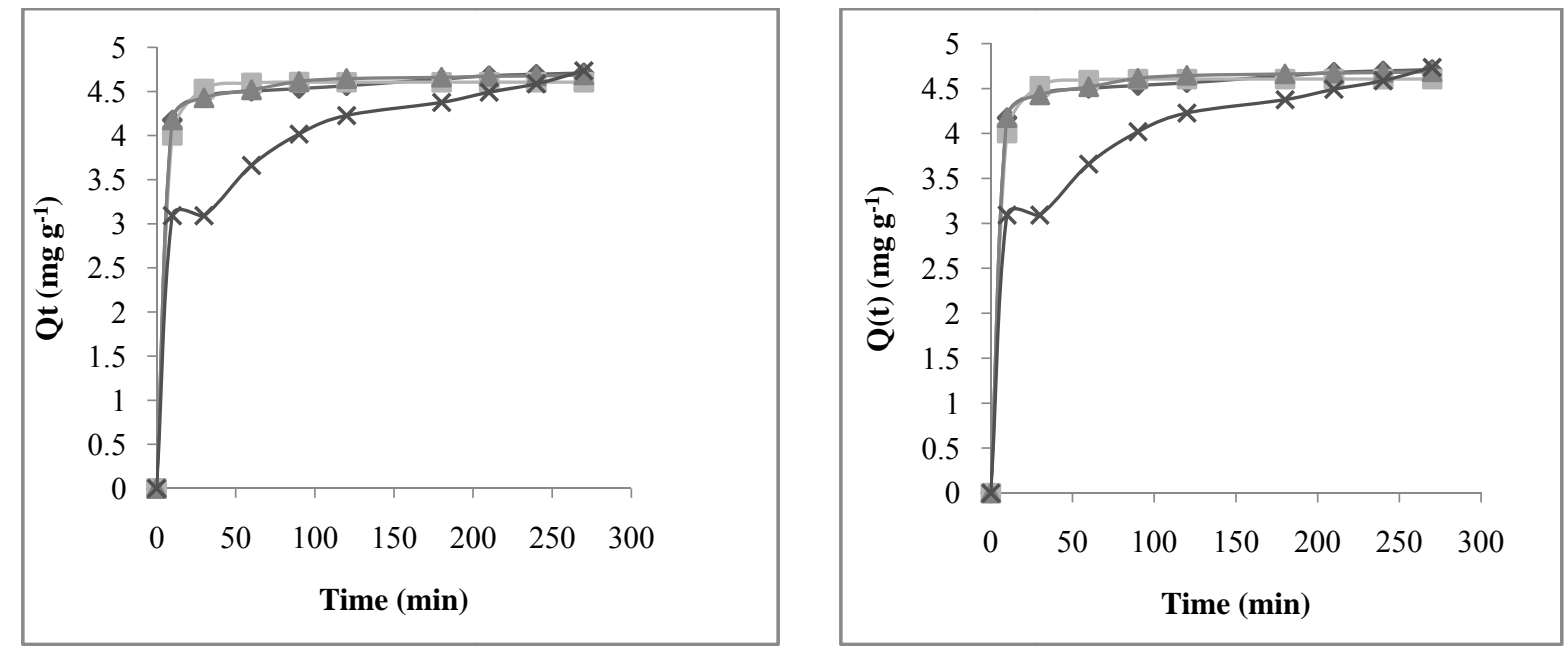

Fig. 4. Adjustment of the kinetic adsorption models of $\mathrm{Pb}$ (II) using lemon peel without pre-treatment (left) and modified with citric acid (right). Note: $(\multimap$ xperimental, $(\multimap$ Pseudo-first order, $(\multimap$ Pseudo-second order and $(\multimap$ Elovich model.

Because it is an organic material of vegetable origin, a high carbon content corresponding to $38.48 \%$ of the sample was observed, values that favor the adsorption of a metallic ion due to its porous characteristics.In addition, a great presence of cellulose with $18.49 \%$ was observed; the presence of these polysaccharides represents an ally in the adsorption due to their structure, which has the presence of groups such as alcohols, acids, phenolic hydroxides, aldehydes and ethers that usually improve the ion exchange capacity of biomass because they are polar compounds[28]. In the spectrum of Fig. 1, the wide and marked peaks of $3330 \mathrm{~cm}^{-1}$ correspond to the $\mathrm{O}-\mathrm{H}$ vibrations due to the stretching of alcohols, phenols and carboxylic acids in pectin, cellulose and lignin, therefore, the presence of "free" hydroxyles on the adsorbent surface is established[24], [35].

The main components of the lemon peel are proteins, pectins, cellulose, pigments and lignin, so the spectrum shows numerous peaks of absorption indicating the complex nature of the adsorbent material[35].Moreover, a $\mathrm{C}-\mathrm{O}$ stretch is observed in the spectrum $1030 \mathrm{~cm}-1$ after the cross-linking process with citric acid, as well as in the band $3500 \mathrm{~cm}^{-1}$ corresponding to the hydroxyl group[36].

In Fig. 2 corresponding to the FTIR spectra for modified and unmodified lemon biomass after lead ion adsorption (II), the change in the bands 300 to 3700 is observed, and in the own 2400 hydroxyl groups present in cellulose, lignin and pectin present in the biomaterial, which shows that the lemon biomass adsorbed citric acid well.In addition, a change is shown in the group that appears at $1700 \mathrm{~cm}^{-1}$, corresponding to the vibrations of ionic carboxylic acids - $\mathrm{COO}$, thus establishing that there are carboxylic and hydroxyl groups in the native biomass and that plays an important role in the adsorption of the ion[36].On the other hand, it also presents the 
results of the FTIR analysis for lemon peel pre-treated with citric acid after the lead adsorption, a C-O stretch band is observed in $1000 \mathrm{~cm}^{-1}$, as well as in $1600 \mathrm{~cm}^{-1}$ corresponding to the vibrations by stretching of the carboxylic ionic groups -COO.In addition, the $3700 \mathrm{~cm}^{-1}$ band also shows vibrations, demonstrating that a high concentration of hydroxyl groups favors the removal of metals, since they allow chelation between the methyl ion to be treated and biomass[36].

The $\mathrm{pH}$ handled in the heavy metal solution influences the biosorption process due to the influence on the main surface sites and the nature of the metal.Figure 3 shows that at higher $\mathrm{pH}$ values $(\mathrm{pH}=6)$ the concentration of hydroxyl is increased, causing changes in the surface of the adsorbent and thus increasing the removal capacity of the metal ion, since the surface could be protonated favouring the adsorption of lead ions which favours the adsorption of lead in its anionic form, which is due to the influence of $\mathrm{pH}$ on surface electrostatic interactions between biomass and metal chemistry[37].

The influence of the particle sizes $0.355,0.5$ and $1 \mathrm{~mm}$ evaluated in this paper are shown in Fig. 3. It is observed that for an intermediate particle size of $0.5 \mathrm{~mm}$ the best metal removal rate was obtained with $97 \%$; however, the three particle sizes tested are suitable for removal of the Lead (II) ion with lemon peel.Although, the decrease in adsorption capacity as the particle size decreases may be due to agglomeration of the particles in the pores of the biomaterial[36].Figure 4 shows that the model that best fits the lead data in the untreated lemon peel treated with citric acid is Pseudo Second Order with an R2 of 0.9586 and 0.9408 , respectively.According to this, the ions are adsorbed in two active biomass sites, which in this case would be the hydroxyl and carboxyl functional groups, making a chemisorption. Removal percentages were obtained after 310 minutes of $97.78 \%$ and $93.83 \%$ contact with the untreated and pre-treated lemon, respectively, with better results with natural biomass were obtained[34], [37].

\section{IV.CONCLUSION}

According to the results obtained in this investigation, it was found that the lemon peel presents a great capacity of adsorption of $\mathrm{Pb}$ (II) ions in synthetic water, since it was able to remove up to $97.78 \%$ obtaining a maximum adsorption capacity of $19,556 \mathrm{mg} / \mathrm{g}$ with $0.5 \mathrm{~g}$ biosorbent dose, however once modified the adsorption capacity was reduced to $93.83 \%$. The best conditions under which the $\mathrm{Pb}$ (II) ion adsorption process was performed were achieved using $\mathrm{pH}$ of 6 and $0.5 \mathrm{~mm}$ particle size.The fitting of the experimental data obtained for the different selected models indicates that the Pseudo Second Order model is the mathematical model that best describes the adsorption kinetics of $\mathrm{Pb}$ (II) for the residual biomass of lemon residual untreated and pre-treated with citric acid.On the other hand, the isothermal model that best describes the results obtained was the one proposed by Freundlich, which proved that the adsorption process is controlled by chemical reaction.

\section{REFERENCES}

[1] Munawar Iqbal and Rasheed A. Khera, "Adsorption of copper and lead in single and binary metal system onto Fumaria indica biomass," Chem. Int., vol. 1, no. 3, p. 157b-163b, 2015

[2] C. P. Ukpaka, E. N. Wami, and S. A. Amadi, "Effect of pollution on metal corrosion : A case study of carbon steel metal in acidic media," vol. 1, no. 4, pp. 107-111, 2015.

[3] S. Madala, V. N. R. Mudumala, S. Vudagandla, and K. Abburi, "Modified leaf biomass for Pb(II) removal from aqueous solution: Application of response surface methodology," Ecol. Eng., vol. 83, pp. 218-226, Oct. 2015.

[4] M. Cabral et al., "Effects of environmental cadmium and lead exposure on adults neighboring a discharge: Evidences of adverse health effects," Environ. Pollut., vol. 206, pp. 247-255, Nov. 2015.

[5] L. M. Adapa, Y. Azimi, S. Singh, D. Porcelli, and I. P. Thompson, "Comparative study of chemical and physical methods for distinguishing between passive and metabolically active mechanisms of water contaminant removal by biofilms,” Water Res., vol. 101, pp. 574-581, Sep. 2016.

[6] R. Emilia, B. Debora, A. Stefania, B. Nicola, and B. Roberto, "Papillifera papillaris (O.F. Müller), a small snail living on stones and monuments, as indicator of metal deposition and bioavailability in urban environments," Ecol. Indic., vol. 69, pp. 360-367, Oct. 2016.

[7] A. K. Zeraatkar, H. Ahmadzadeh, A. F. Talebi, N. R. Moheimani, and M. P. McHenry, "Potential use of algae for heavy metal bioremediation, a critical review," J. Environ. Manage., vol. 181, pp. 817-831, Oct. 2016.

[8] L. Nyaba, J. M. Matong, K. M. Dimpe, and P. N. Nomngongo, "Speciation of inorganic selenium in environmental samples after suspended dispersive solid phase microextraction combined with inductively coupled plasma spectrometric determination," Talanta, vol. 159, pp. 174-180, Oct. 2016.

[9] H. K. Hansen, C. Gutierrez, J. Callejas, and C. Cameselle, "Biosorption of lead from acidic aqueous solutions using Durvillaea antarctica as adsorbent,” Miner. Eng., vol. 46-47, pp. 95-99, Jun. 2013.

[10] C. T. Tejada, Á. Villabona Ortiz, and M. Jiménez Villadiego, Removing of hexavalent chromium on chemically pretreated cacao wasted, vol. 20, no. 1. Universidad de Ciencias Aplicadas y Ambientales, 2017.

[11] N. Gaur, G. Flora, M. Yadav, and A. Tiwari, "A review with recent advancements on bioremediation-based abolition of heavy metals," Environ. Sci. Process. Impacts, vol. 16, no. 2, pp. 180-193, 2014.

[12] S. Mor, K. Chhoden, and K. Ravindra, "Application of agro-waste rice husk ash for the removal of phosphate from the wastewater," J. Clean. Prod., vol. 129, pp. 673-680, Aug. 2016.

[13] X. Yu et al., "Adsorption of heavy metal ions from aqueous solution by carboxylated cellulose nanocrystals,” J. Environ. Sci., vol. 25, no. 5, pp. 933-943, May 2013.

[14] M. Saeed, S. Adeel, M. Azhar Shahzad, M. Muneer, and M. Younas, "Pt/A12 O3 Catalyzed Decolorization of Rhodamine B Dye in Aqueous Medium,” Chiang Mai J. Sci, vol. 42, no. 3, pp. 730-744, 2015.

[15] J. He and J. P. Chen, "A comprehensive review on biosorption of heavy metals by algal biomass: Materials, performances, chemistry, and modeling simulation tools,” Bioresour. Technol., vol. 160, pp. 67-78, May 2014. 
[16] L. Cutillas-Barreiro et al., "Valorization of biosorbent obtained from a forestry waste: Competitive adsorption, desorption and transport of $\mathrm{Cd}, \mathrm{Cu}, \mathrm{Ni}, \mathrm{Pb}$ and $\mathrm{Zn}$,” Ecotoxicol. Environ. Saf., vol. 131, pp. 118-126, Sep. 2016.

[17] H. T. Tran et al., "Heavy metal biosorption from aqueous solutions by algae inhabiting rice paddies in Vietnam," J. Environ. Chem. Eng., vol. 4, no. 2, pp. 2529-2535, Jun. 2016.

[18] W. J. Chu, P. S. Peh, and Y. Wang, "Biosorption adsorption of metal ions using lemon peel powder," 2014.

[19] Y.-L. Chen et al., "Biosorption of Cr (VI) by Typha angustifolia: Mechanism and responses to heavy metal stress," Bioresour. Technol., vol. 160, pp. 89-92, May 2014.

[20] C. N. Tejada, Z. Montiel, and D. Acevedo, "Aprovechamiento de Cáscaras de Yuca y Ñame para el Tratamiento de Aguas Residuales Contaminadas con Pb(II)," Inf. tecnológica, vol. 27, no. 1, pp. 09-20, 2016.

[21] S. Amirnia, M. B. Ray, and A. Margaritis, "Heavy metals removal from aqueous solutions using Saccharomyces cerevisiae in a novel continuous bioreactor-biosorption system,” Chem. Eng. J., vol. 264, pp. 863-872, Mar. 2015.

[22] Y. Cheng, C. Yang, H. He, G. Zeng, K. Zhao, and Z. Yan, "Biosorption of Pb(II) Ions from Aqueous Solutions by Waste Biomass from Biotrickling Filters: Kinetics, Isotherms, and Thermodynamics," J. Environ. Eng., vol. 142, no. 9, p. C4015001, Sep. 2016.

[23] N. A. Fathy, S. T. El-Wakeel, and R. R. Abd El-Latif, "Biosorption and desorption studies on chromium(VI) by novel biosorbents of raw rutin and rutin resin,” J. Environ. Chem. Eng., vol. 3, no. 2, pp. 1137-1145, Jun. 2015.

[24] M. J. K. Ahmed and M. Ahmaruzzaman, "A review on potential usage of industrial waste materials for binding heavy metal ions from aqueous solutions," J. Water Process Eng., vol. 10, pp. 39-47, Apr. 2016.

[25] R. García, J. Campos, J. A. Cruz, M. E. Calderón, M. E. Raynal, and G. Buitrón, "Biosorption of CD, CR, MN, and PB from aqueous solutions by Bacillus SP strains trains isolated from industrial waste activate sludge," TIP, vol. 19, no. 1, pp. 5-14, Jan. 2016.

[26] M. Ajmal, S. Adeel, M. Azeem, M. Zuber, N. Akhtar, and N. Iqbal, "Modulation of pomegranate peel colourant characteristics for textile dyeing using high energy radiations," Ind. Crops Prod., vol. 58, pp. 188-193, Jul. 2014.

[27] J. Singh and B.-K. Lee, "Reduction of environmental availability and ecological risk of heavy metals in automobile shredder residues," Ecol. Eng., vol. 81, pp. 76-81, Aug. 2015.

[28] C. Tejada Tovar, E. Ruiz Paternina, J. Gallo Mercado, and J. Moscote Bohorquez, "Evaluación de la biosorción con bagazo de palma africana para la eliminación de Pb (II) en solución,” Prospectiva, vol. 13, no. 1, p. 59, Jun. 2015.

[29] A. Ronda, M. A. Martín-Lara, A. I. Almendros, A. Pérez, and G. Blázquez, "Comparison of two models for the biosorption of Pb(II) using untreated and chemically treated olive stone: Experimental design methodology and adaptive neural fuzzy inference system (ANFIS)," J. Taiwan Inst. Chem. Eng., vol. 54, pp. 45-56, Sep. 2015.

[30] L. Vizcaíno Mendoza and N. Fuentes Molina, "Biosorción de Cd, Pb y Zn por biomasa pretratada de algas rojas, cáscara de naranja y tuna," Cienc. e Ing. Neogranadina, vol. 25, no. 1, pp. 43-60, 2015.

[31] C. Tejada, A. Herrera, and J. Nuñez, "Adsorción competitiva de $\mathrm{Ni}$ (II) y Pb (II) sobre materiales residuales lignocelulósicos," Investig. Andin., vol. 17, no. 31, pp. 1355-1367, 2015.

[32] T. Li et al., "Removal of lead(II) from aqueous solution with ethylenediamine-modified yeast biomass coated with magnetic chitosan microparticles: Kinetic and equilibrium modeling,” Chem. Eng. J., vol. 214, pp. 189-197, Jan. 2013.

[33] M. B. Ahmed, J. L. Zhou, H. H. Ngo, W. Guo, and M. Chen, "Progress in the preparation and application of modified biochar for improved contaminant removal from water and wastewater," Bioresour. Technol., vol. 214, pp. 836-851, Aug. 2016.

[34] L. Tejeda Benítez, C. Tejada Tovar, W. Marimón Bolívar, and Á. Villabona Ortiz, "Estudio de modificación química y física de biomasa (Citrus sinensis y Musa paradisiaca) para la adsorción de metales pesados en solución.," Rev. Luna Azul, vol. 39, no. 1, pp. 124-142, 2014.

[35] R. C. Oliveira, P. Hammer, E. Guibal, J.-M. Taulemesse, and O. Garcia, "Characterization of metal-biomass interactions in the lanthanum(III) biosorption on Sargassum sp. using SEM/EDX, FTIR, and XPS: Preliminary studies," Chem. Eng. J., vol. 239, pp. 381-391, Mar. 2014.

[36] C. T. Tovar and A. Herrera, "Remoción de plomo por biomasas residuales de cáscara de naranja (Citrus sinensis) y zuro de maíz (Zea mays) removal of lead using residual biomass of of orange peel and corncob," pp. 169-178, 2016.

[37] F. Oré Jiménez, C. Lavado Meza, and S. Bendezú Montes, "Biosorción de Pb (II) de aguas residuales de mina usando el marlo de maíz (Zea mays)," Rev. la Soc. Química del Perú, vol. 81, no. 2, pp. 122-134, 2015. 